\title{
Nitrogen metabolism and rumen microbial enumeration in lactating cows with divergent residual feed intake fed high-digestibility pasture
}

\author{
A. G. Rius, ${ }^{\star 1}$ S. Kittelmann, $†$ K. A. Macdonald, ${ }^{\star}$ G. C. Waghorn, ${ }^{\star}$ P. H. Janssen, $†$ and E. Sikkema‡ \\ *DairyNZ Ltd., Private Bag 3221, Hamilton 3240, New Zealand \\ †AgResearch Grasslands, Private Bag 11008, Palmerston North, New Zealand \\ $\ddagger$ Wageningen University, Wageningen, $6700 \mathrm{PG}$, the Netherlands
}

\section{ABSTRACT}

Dairy cattle selected for negative residual feed intake (n-RFI; efficient) should maintain production while reducing dry matter intake over a lactation because of improvements in feed digestion and efficient use of nutrients. The objective of this study was to measure nitrogen $(\mathrm{N})$ digestibility and rumen microbial community composition over a short period during early lactation in lactating Holstein-Friesian cows selected previously for divergent RFI. It was proposed that nRFI cows would have greater apparent digestibility of $\mathrm{N}$ than the positive RFI (p-RFI; inefficient) animals, to compensate for the lower dry matter intake determined during selection for divergence. Sixteen 3-yr-old rumencannulated, lactating cows (56 $\pm 10 \mathrm{~d}$ in milk) selected for $\mathrm{n}$-RFI $(\mathrm{n}=8)$ and $\mathrm{p}$-RFI $(\mathrm{n}=8)$ were housed in metabolism stalls and fed fresh vegetative ryegrass (Lolium perenne L.) pasture ad libitum as a sole diet during an 8-d digestibility study. Intake of nutrients and outputs of milk, feces, and urine were determined. Rumen parameters were determined by removing, weighing, and sampling digesta, and by cobalt-EDTA dilution. Intakes of $\mathrm{N}$, dry matter, organic matter, or its components did not differ with RFI. Compared with p-RFI cows, n-RFI cows had a greater apparent $\mathrm{N}$ digestibility (77.2 vs. $75.5 \%$ ), and a tendency toward greater dry matter and organic matter digestibilities. The n-RFI cows had a lower fecal N output (126 vs. 138 $\mathrm{g} / \mathrm{d}$ ) and a lower partition of feed $\mathrm{N}$ to fecal $\mathrm{N}$ (23.1 vs. $24.7 \%$ ) compared with p-RFI animals. We found no differences between phenotypes in the partition of $\mathrm{N}$ to urinary $\mathrm{N}$ or milk crude protein but did observe a trend for $\mathrm{n}$-RFI cows to partition less $\mathrm{N}$ to milk casein (16.8 vs. $17.9 \%)$. Rumen digesta mass was similar for both groups, despite differences in calculated fractional liquid outflow rates, and most bacterial, archaeal, protozoal, and fungal communities were similar for both

Received January 30, 2012.

Accepted May 10, 2012.

${ }^{1}$ Corresponding author: Agustin.Rius@dairynz.co.nz phenotype groups. In conclusion, dry matter intake and rumen function were similar for both phenotypes when the animals were fed highly digestible fresh ryegrass, but apparent digestibility of dietary $\mathrm{N}$ was higher in the efficient (n-RFI) cows. Future research should measure digestion parameters in cows with divergent RFI when fed diets differing in chemical composition (e.g., divergent crude protein contents).

Key words: residual feed intake, nitrogen partitioning, rumen microbial communities

\section{INTRODUCTION}

The efficiency of nitrogen use for milk production by cows fed ryegrass pasture is low, with 15 to $30 \%$ of $\mathrm{N}$ consumed partitioned into milk (Van Vuuren et al., 1992; NRC, 2001). Most N consumed is excreted, and urinary $\mathrm{N}$ is implicated in ground water contamination and can be a significant contributor to nitrous oxide emissions. The importance of urinary $\mathrm{N}$ excretion can be greater when fresh temperate pastures (ryegrass/ clover) are fertilized with $\mathrm{N}$ to stimulate growth in intensive dairying (Van Vuuren et al., 1992) because $\mathrm{N}$ intake greatly exceeds requirements for milk production (NRC, 2001). Values for ryegrass pastures frequently exceed $4 \% \mathrm{~N}$ of DM, and although the benefits of reducing $\mathrm{CP}$ and RDP intakes for lowering $\mathrm{N}$ outputs in urine and feces are well known (Cyriac et al., 2008; Broderick and Reynal, 2009; Rius et al., 2010), reductions in $\mathrm{N}$ concentrations in ryegrass-dominant pastures are associated with lower forage quality and pasture growth. Strategies to reduce urinary N excretion from cows grazing pasture while maintaining productivity include lowering feed intakes by selecting efficient animals that require less feed or partition more dietary $\mathrm{N}$ to milk and feces.

Residual feed intake (RFI) is a trait used to select for feed use efficiency in farm animals. Steers selected for negative RFI (n-RFI; efficient) have a lower DMI compared with those selected for positive RFI (p-RFI; inefficient), even though production and final $\mathrm{BW}$ are not affected (Nkrumah et al., 2006; Hegarty et al., 
2007; Herd and Arthur, 2009). Herd and Arthur (2009) and Nkrumah et al. (2006) suggested that about onethird of the variation in steers selected for divergent RFI was explained by processes associated with feed digestion and behavior, and two-thirds by differences in heat production due to changes in metabolism (e.g., energy cost of maintenance), body composition, and physical activity.

Previously, Richardson et al. (1996) reported that beef heifers ranked as n-RFI had $1 \%$ greater DM digestibility than heifers identified as p-RFI when animals were fed a diet of $70 \%$ alfalfa hay plus $30 \%$ concentrate, and differences in digestibility accounted for $14 \%$ of the total variation in RFI. In comparison, however, Lawrence et al. (2011) found no difference in DM digestibility in heifers selected for divergent RFI and fed perennial ryegrass silage. The difference between the 2 trials may have been a consequence of the diet or differences in the gastrointestinal tract mass, which Basarab et al. (2003) reported to be lower in n-RFI steers fed mostly silage, compared with less efficient p-RFI steers. The intakes of fresh pasture will be greater than either silage or dry diets (i.e., hay or grain-based diet), by virtue of the water content of fresh pasture, and we are not aware of any digestibility comparisons in lactating cows selected for divergent RFI fed high-digestible fresh pasture.

Digestibility varies between individuals (Titgemeyer, 1997) and is affected by physiological state, physical and chemical characteristics of the diet, intake, and feed availability. Measurements of rumen digesta weights and outflow rates may provide an indication of animal characteristics likely to affect digestion, and the microflora can be a reflection of host physiology (Weimer et al., 2010). A previous study has not supported differences in microbial communities in cattle with divergent RFI phenotypes fed grain-based diets (Krueger et al., 2009b). The trial reported here provides an initial evaluation of the effects of a fresh pasture diet on rumen parameters and the microbial community structure in dairy cattle selected for divergent RFI.

The objective of this study was to measure digestibility of DM, OM, and N, and partitioning of $\mathrm{N}$, as well as the composition of the rumen microbial community, in lactating dairy cows selected for divergent RFI and fed high-digestible pasture. We hypothesized that cows selected for n-RFI have greater apparent digestibility of $\mathrm{N}$ to compensate for lower DMI.

\section{MATERIALS AND METHODS}

\section{Animals}

This research was conducted at Lye Farm, DairyNZ (Hamilton, New Zealand), and all animal procedures were approved by the Ruakura Animal Ethics Committee (Hamilton, New Zealand). Sixteen 3-yr-old, Holstein-Friesian $(\mathrm{BW}=459 \pm 28 \mathrm{~kg}$; mean $\pm \mathrm{SD})$, rumen-cannulated, lactating cows $(56 \pm 10 \mathrm{DIM})$ were used. Cows were selected for p-RFI $(\mathrm{n}=8)$ and n-RFI $(\mathrm{n}=8)$ as 8 -mo-old weaned heifers $(\mathrm{BW}=219 \mathrm{~kg})$ fed alfalfa cubes for $42 \mathrm{~d}$, and RFI was determined by multiple regression of DMI on growth rate and mean metabolic weight as described by Waghorn et al. (2012). When the RFI was determined from the residuals of the regression analysis, the range was from -2.2 (n-RFI) to +1.5 (p-RFI) $\pm 0.54 \mathrm{~kg}$ of $\mathrm{DM} / \mathrm{d}$ (Carnie et al., 2010). The short duration and experimental conditions used in the current experiment are not conducive to an assessment of RFI.

\section{Digestibility Study}

The cows were moved from paddock into individual metabolism stalls to adapt to the indoor environment for $3 \mathrm{~d}$ (acclimation), followed by an 8-d period in which total feces and urine were collected. Harnesses were fitted for attaching fecal collection chutes and urine deflectors fitted as described by Meier et al. (2008) so that feces and urine could be collected separately from individual animals. Fresh ryegrass-dominant pasture was harvested twice daily and cows were fed at 0900 and $1600 \mathrm{~h}$ throughout the experiment to enable ad libitum intakes, with 5 to $10 \%$ refused daily. Samples of pasture were collected twice daily throughout the experiment for $\mathrm{DM}$ determination (in triplicate) at $105^{\circ} \mathrm{C}$ for $24 \mathrm{~h}$ (Horowitz and Latimer, 2005). Individual cow refusals were weighed and sampled before the $0900 \mathrm{~h}$ feeding for DM determination, combined by cow and day, and analyzed for chemical composition. Samples of pasture offered and refused were oven-dried at $60^{\circ} \mathrm{C}$ until dry, ground to pass through a 1-mm mesh, and chemically analyzed (Feedtech, Palmerston North, New Zealand).

Daily fecal excreta were collected in 100-L containers, weighed, and mixed; aliquots (1\%, wet weight) were pooled by cow and stored at $-20^{\circ} \mathrm{C}$. Fecal samples were collected and either dried at $105^{\circ} \mathrm{C}$ to determine the DM or freeze-dried and ground to pass through a 1-mm screen for analysis of N, ADF, NDF, lignin, and ash. Urine output was collected in 100-L lidded containers and weighed daily. Urine aliquots $(0.1 \%$ of daily volume) were collected, pooled by cow, and stored at $-20^{\circ} \mathrm{C}$ for analysis of N. Nitrogen determination in all samples was by the Leco total combustion method (AOAC method 968.06; Horowitz and Latimer, 2005), and feed, refusals, and fecal NDF, ADF, and lignin by the Tecator Fibertec system (Robertson and Van Soest, 1981). Ash was measured following incineration at 
$550^{\circ} \mathrm{C}$ (AOAC method 942.05; Horowitz and Latimer, 2005).

Cows were milked at 0700 and $1500 \mathrm{~h}$, and samples were collected and pooled on d 3, 5, and 7 for determination of milk urea and fat, CP, true protein, casein, and lactose concentrations by Milkoscan (Foss Electric, Hillerød, Denmark). Milk urea concentrations were determined by enzymatic UV assay (Alpha Scientific, Hamilton, New Zealand). Milk $\mathrm{NE}_{\mathrm{L}}$ was calculated as $\mathrm{NE}_{\mathrm{L}}(\mathrm{MJ} / \mathrm{kg})=4.186 \times[(0.0929 \times$ fat $\%)+(0.0547 \times$ $\mathrm{CP} \%)+(0.0395 \times$ lactose \% $)](\mathrm{NRC}, 2001)$, and $4 \%$ FCM $(\mathrm{kg} / \mathrm{d})$ production was calculated as $(0.4 \times \mathrm{kg}$ of milk/d) $+(15 \times \mathrm{kg}$ of fat $/ \mathrm{d})$ (Gaines and Davidson, 1923). Cow BW were measured weekly immediately before and after the digestibility study, and BW data were analyzed to estimate body mass gained throughout the study.

\section{Microbial Composition}

Four rumen digesta grab samples (liquid + solid; mid-rumen) were taken via the cannula and were used to obtain a single subsample per cow per date. Samples were collected on d 2 and 6 of the experimental period

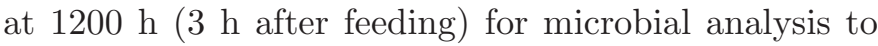
determine community composition of bacteria, archaea, protozoa, and fungi described below. The samples were frozen $\left(-20^{\circ} \mathrm{C}\right)$ immediately after sampling. Samples from all 16 animals on both days were analyzed (i.e., 32 samples).

DNA Extraction. The DNA was extracted from $30 \mathrm{mg}$ of each homogenized, freeze-dried, and ground digesta sample using an extraction protocol that combined mechanical (bead-beating) and chemical (phenolchloroform) disruption of cells (J. J. Faith, Center for Genome Sciences and Systems Biology, St. Louis, MO; personal communication). Cells were disrupted by bead-beating in a FastPrep FP120 cell disruptor (Qbiogene, Carlsbad, CA) at $6.5 \mathrm{~m} / \mathrm{s}$ for $45 \mathrm{~s}$ in the presence of $0.7 \mathrm{~g}$ of zirconium beads, $282 \mu \mathrm{L}$ of buffer $\mathrm{A}(\mathrm{NaCl}$ $0.2 M$, Tris $0.2 M$, EDTA $0.02 M$; pH 8), $268 \mu \mathrm{L}$ of buffer PM (QIAquick 96 PCR purification kit, Qiagen, Valencia, CA), $200 \mu \mathrm{L}$ of $20 \%$ SDS, and $550 \mu \mathrm{L}$ of a phenol-chloroform-isoamyl alcohol mixture (25:24:1, vol:vol:vol, $\mathrm{pH} 8)$. After centrifugation $(18,000 \times g$ for 20 min at $4^{\circ} \mathrm{C}$ ), the supernatant was thoroughly mixed with $650 \mu \mathrm{L}$ of buffer PM (Qiagen) and transferred onto a column (QIAquick 96 PCR purification kit) to bind the extracted DNA to the membrane. Bound DNA was washed with $700 \mu \mathrm{L}$ of buffer PE (Qiagen) followed by elution into sterile tubes with $80 \mu \mathrm{L}$ of elution buffer (10 mM Tris, pH 8.5 with $\mathrm{HCl}$ ).
Amplification and Sequencing of Target Genes. Primers used for PCR amplification of bacterial and archaeal 16S rRNA genes, ciliate protozoal 18S rRNA genes, and fungal internal transcribed spacer 1 regions (ITS-1) were synthesized by Integrated DNA Technologies Inc. (Coralville, IA). All primers contained the 454 Life Science adaptor A (5'-CCA TCT CAT CCC TGC GTG TCT CCG ACT CAG-3') or B (5'-CCT ATC CCC TGT GTG CCT TGG CAG TCT CAG-3') for titanium sequencing and a 2-base linker sequence between the barcode and the group-specific primer. A unique 12-bp error-correcting Golay barcode was attached to adaptor A for sample identification (Fierer et al., 2008). Amplification of target DNA was performed as described by Kittelmann et al. (2012). Triplicate PCR products were pooled, and the correct sizes of PCR products and signal absence from the negative controls were verified by agarose gel electrophoresis. Amplicons were quantified using the Qubit dsDNA BR assay kit (Invitrogen, Carlsbad, CA) on a fluorometer (BioTek Instruments, Winooski, VT), normalized, and pooled. A total of $1 \mu \mathrm{g}$ of DNA of each of the 4 pools was loaded onto an agarose gel (1\%, wt:vol). Bands were visualized and excised under blue light transillumination, and amplicons were gel purified with the Qiaquick gel extraction kit (Qiagen). Gel-purified amplicon pools were quantified in triplicate using the Qubit dsDNA HS assay kit (Invitrogen) and diluted to obtain $2 \times 10^{5}$ copies $/ \mu \mathrm{L}$ in each pool. Emulsion PCR was performed using the GS Titanium emPCR reagents LV (LIB-L; Roche Diagnostics, Brandford, CT). The DNA-positive beads were enriched, counted on a Z1 particle counter (Beckman Coulter, Brea, CA), and loaded onto a picotiter plate for pyrosequencing on a 454 Life Sciences Genome Sequencer FLX machine (Roche Diagnostics).

Phylogenetic Analysis of Pyrosequencing Reads. Samples were processed and analyzed following the procedure described by Caporaso et al. (2010). Sequences $>200 \mathrm{bp}$ in length were truncated so that the average quality score was $>25$ and only sequences without ambiguous characters were included in the analyses. Sequence reads were assigned to corresponding samples by examining the 12-bp error-correcting Golay barcodes. Sequence data were assigned to phylogenetic groups in QIIME v1.2.1 (Caporaso et al., 2010). Bacterial 16S rRNA genes were blasted against the greengenes database (DeSantis et al., 2006), whereas archaeal 16S rRNA genes, protozoal 18S rRNA genes, and fungal ITS-1 genes were blasted against rumenspecific BLAST databases established earlier (Janssen and Kirs, 2008; Kittelmann and Janssen, 2011; Kit- 
telmann et al., 2012). Sequence data of bacterial and archaeal 16S rRNA genes, ciliate 18S rRNA genes, and anaerobic fungal ITS1 genes obtained in this study are deposited in MG-RAST (http://metagenomics.anl. gov/) under IDs 4491446.3-4491449.3. Only samples with identifiers including the abbreviations "SepRT" and "OctRT" were used in this study.

\section{Rumen pH, Ammonia, and VFA}

Rumen liquor samples were collected to determine $\mathrm{pH}$, ammonia $\left(\mathrm{NH}_{3}\right)$, and VFA at 0600, 1200, 1800, and $2400 \mathrm{~h}$ on $\mathrm{d} 6$ of the experimental period. Liquor pH was measured (MeterLab PHM210, Radiometer Pacific Limited, Copenhagen, Denmark), and the rumen liquor was subsequently centrifuged $(1,000 \times g$ for 10 min at $4^{\circ} \mathrm{C}$ ) for subsampling. Aliquots of supernatant were acidified using $0.5 \mathrm{M} \mathrm{HCl}$ and stored at $-20^{\circ} \mathrm{C}$ for $\mathrm{NH}_{3}$ analysis (enzymatic determination using glutamate dehydrogenase). A second set of aliquots was stored at $-20^{\circ} \mathrm{C}$ before VFA determination following deproteination using metaphosphoric acid, by gas chromatograph (Carlo Erba 5380, capillary column, $15 \mathrm{~m}$ $\times 0.53 \mathrm{~mm}$ ID, $1.00 \mu \mathrm{m}$ film, Carlo Erba, Milan, Italy) using $\mathrm{H}_{2}$ as the carrier gas and iso-caproic acid as an internal standard (Wronkowska et al., 2006)

\section{Rumen Bailing and Marker Dilution}

Rumen digesta pools were determined by emptying (and return) of digesta via the cannula and by marker dilution using Co-EDTA liquid flow marker. Rumen digesta were removed on 2 occasions (d 3 of the acclimation period and d 8 of the digestibility study) for all cows. Digesta were removed from 8 cows $(4 \mathrm{n}-\mathrm{RFI}$ and $4 \mathrm{p}-\mathrm{RFI})$ before feeding $(0700 \mathrm{~h})$ and from 8 cows after they had been eating for $2 \mathrm{~h}$, when most cows had stopped eating $(1100 \mathrm{~h})$. Cows bailed before feeding on d 3 of the acclimation period were bailed after feeding on d 8 of the digestibility study and cows bailed after feeding on $\mathrm{d} 3$ of the acclimation period were bailed before feeding on $\mathrm{d} 8$. The digesta were weighed, mixed thoroughly, sampled to determine DM content, and returned to the cows within $20 \mathrm{~min}$.

Water intake was measured at all times and although cows were fed twice daily and could not be considered as reaching "steady state," an attempt was made to determine rumen liquid volumes and fractional outflow rate (FOR) using marker dilution. A Co-EDTA stock solution (Udén et al., 1980) was administered $(450 \mathrm{~mL}$; $\sim 1.8 \mathrm{~g}$ of cobalt per cow) in a single dose to the midrumen via the cannula to all cows at $1100 \mathrm{~h}$ on $\mathrm{d} 7$ of the experimental period. Rumen liquor was sampled before marker administration and at 1,2, 4, 6, 8, and $11 \mathrm{~h}$ post-administration, and samples were stored at $-20^{\circ} \mathrm{C}$ until cobalt concentrations were determined using inductively coupled plasma emission spectroscopy (NZlabs, Hamilton, New Zealand). Rumen cobalt dilution and outflow of the rumen liquor were estimated following log-transformation of the data (Warner and Stacy, 1968).

\section{Statistical Analysis}

The parameters of interest (except microbial data) were analyzed using the following statistical model:

$$
\mathrm{Y}_{\mathrm{ij}}=\mu+\beta+\tau_{\mathrm{i}}+\mathrm{E}_{(\mathrm{i}) \mathrm{j}},
$$

where $Y_{\mathrm{ij}}=$ the dependent variable, $\mu=$ the overall mean, $\beta=$ the covariate effect of DIM, $\tau_{\mathrm{i}}=$ the fixed effect of ith treatment group (i = n-RFI, p-RFI), and $\mathrm{E}_{(\mathrm{i}) \mathrm{j}}$ $=$ the random effect of error (cow). Data were analyzed using calculated means over the experimental period per cow for each variable in ANOVA.

Sequence data were grouped into operational taxonomic units sharing more than $97 \%$ (bacteria, archaeal) or $100 \%$ (ciliate protozoa, fungi) sequence similarity. The operational taxonomic units were then summarized at the family (bacteria), genus (ciliate protozoa), or sub-genus (archaeal, fungi) level using the QIIME pipeline (Caporaso et al., 2010). Phylogenetic groups with an abundance of less than $1 \%$ of the total community were excluded from further statistical analyses. Treatment group and sampling day were tested by ANOVA. All data were analyzed using the statistical package Genstat 14.1 (13th ed., 2011; VSN International, Hemel Hempstead, UK). A probability of $\leq 0.05$ was used to determine statistical significance unless otherwise noted.

Table 1. Dry matter (\%) and chemical composition (\% of DM basis) of the pasture offered to lactating dairy cows selected for divergent residual feed intake

\begin{tabular}{lcl}
\hline Item & Mean & SD \\
\hline DM & 14.9 & 2.65 \\
Nitrogen & 3.72 & 0.26 \\
CP & 23.1 & 1.60 \\
NDF & 36.4 & 0.91 \\
ADF & 17.6 & 1.01 \\
Lignin & 2.30 & 0.72 \\
Ash & 9.30 & 0.43 \\
\hline
\end{tabular}


Table 2. Intake and apparent digestibility of lactating cows selected for negative residual feed intake (n-RFI) and positive residual feed intake (p-RFI) and fed high-quality pasture

\begin{tabular}{lcccc}
\hline Item & n-RFI & p-RFI & SED $^{1}$ & $P$-value \\
\hline Intake & & & & \\
DM, kg/d & 15.2 & 15.7 & 0.49 & 0.32 \\
OM, kg/d & 13.7 & 14.0 & 0.40 & 0.40 \\
N, g/d & 543 & 558 & 17.1 & 0.40 \\
NDF, kg/d & 5.28 & 5.41 & 0.15 & 0.40 \\
ADF, kg/d & 2.53 & 2.59 & 0.07 & 0.40 \\
Apparent digestibility & & & & 0.07 \\
DM, & 78.5 & 77.3 & 0.62 & 0.08 \\
OM, \% & 81.1 & 80.1 & 0.57 & 0.02 \\
N, \% & 77.2 & 75.5 & 0.69 & 0.37 \\
NDF, \% & 90.2 & 89.6 & 0.61 & 0.37 \\
ADF, \% & 79.5 & 78.3 & 1.27 & \\
\hline
\end{tabular}

${ }^{1} \mathrm{SED}=$ standard error of the difference.

${ }^{2}$ Apparent digestibility $=($ intake - feces $) /$ intake $\times 100$.

\section{RESULTS}

\section{Intake, Diet, and Digestibility}

The pasture offered to cows comprised (DM basis) $96 \%$ perennial ryegrass (Lolium perenne), $2 \%$ white clover (Trifolium repens), and $2 \%$ other grasses. The pasture was of consistent quality over the feeding period, and the chemical composition is presented in Table 1 . Intake of DM and its components did not differ between treatment groups (Table 2), with daily values averaging $15.5 \mathrm{~kg}$ of DM and $550 \mathrm{~g}$ of N. The n-RFI cows had greater apparent $\mathrm{N}$ digestibility (77.2 vs. $75.5 \%$; $P<0.05)$ and a trend $(P<0.1)$ to a greater apparent digestibility of DM and OM than p-RFI cows (Table 2 ). Cow BW throughout the experiment was similar for both groups, averaging $467 \pm 12 \mathrm{~kg}$.

\section{Partition of Nitrogen}

Nitrogen output in milk was $9 \%$ less in n-RFI cows $(P<0.05$; Table 3$)$, but we observed no differences be- tween groups for milk weight, milk $\mathrm{CP}$, or true protein when expressed in terms of dietary $\mathrm{N}$ intake. However, we found a trend $(P=0.06)$ for higher partitioning of dietary $\mathrm{N}$ to casein in p-RFI cows, which also had a lower milk urea concentration $(P<0.001)$ than n-RFI cows (Table 4). Yields of $4 \%$ FCM, CP, true protein, casein, and fat $(P<0.05)$ were lower in n-RFI than in p-RFI cows (Table 4).

The n-RFI cows had $9 \%$ less fecal $\mathrm{N}$ output than $\mathrm{p}$ RFI cows (126 vs. $138 \mathrm{~g} / \mathrm{d} ; P<0.05$ ), and less dietary $\mathrm{N}$ was partitioned to feces in the n-RFI (efficient) cows (Table 3). The output and partition of dietary $\mathrm{N}$ to urine was not affected by phenotype (Table 3 ).

\section{Rumen Metabolites and Liquid Pool}

Rumen $\mathrm{NH}_{3}$ concentrations were greater in n-RFI cows (15.5 vs. $12.9 \mathrm{mM} ; P<0.01)$, but VFA concentrations and molar ratios or rumen $\mathrm{pH}$ did not differ between treatment groups (Table 5). The $\mathrm{NH}_{3}$ concentrations showed substantial diurnal variation, with means

Table 3. Nitrogen output and partitioning in lactating cows selected for negative residual feed intake (n-RFI) and positive residual feed intake (p-RFI) and fed high-quality pasture

\begin{tabular}{lcccc}
\hline Item & n-RFI & p-RFI & SED $^{1}$ & $P$-value \\
\hline N intake, g/d & 543 & 558 & 17.1 & 0.40 \\
N output, g/d & & & & \\
$\quad$ Milk & 116 & 127 & 5.0 & 0.04 \\
Feces & 126 & 138 & 5.1 & 0.04 \\
$\quad$ Urine & 271 & 271 & 16.2 & 0.98 \\
N output, \% of N intake & & & & \\
Milk CP & 21.5 & 22.6 & 0.66 & 0.12 \\
Milk true protein & 20.1 & 21.2 & 0.61 & 0.10 \\
Milk casein & 16.8 & 17.9 & 0.51 & 0.06 \\
Feces & 23.1 & 24.7 & 0.76 & 0.05 \\
Urine & 50.0 & 48.7 & 2.85 & 0.73 \\
\hline
\end{tabular}

${ }^{1} \mathrm{SED}=$ standard error of the difference. 
Table 4. Milk production in cows selected for negative residual feed intake (n-RFI) and positive residual feed intake (p-RFI) and fed high-quality pasture

\begin{tabular}{|c|c|c|c|c|}
\hline Item & n-RFI & p-RFI & $\mathrm{SED}^{1}$ & $P$-value \\
\hline Milk yield, kg/d & 22.2 & 24.7 & 1.3 & 0.08 \\
\hline $4 \% \mathrm{FCM}^{2}, \mathrm{~kg} / \mathrm{d}$ & 22.6 & 25.3 & 1.2 & 0.04 \\
\hline $\mathrm{NE}_{\mathrm{L}},{ }^{3} \mathrm{MJ} / \mathrm{kg}$ & 3.18 & 3.21 & 0.07 & 0.66 \\
\hline \multicolumn{5}{|c|}{ Milk composition, $\%$} \\
\hline $\mathrm{CP}$ & 3.34 & 3.30 & 0.12 & 0.70 \\
\hline True protein & 3.14 & 3.10 & 0.12 & 0.79 \\
\hline Casein & 2.62 & 2.61 & 0.10 & 0.96 \\
\hline Fat & 4.12 & 4.21 & 0.14 & 0.54 \\
\hline Lactose & 4.91 & 4.96 & 0.03 & 0.13 \\
\hline \multicolumn{5}{|c|}{ Yields of milk components, $\mathrm{kg} / \mathrm{d}$} \\
\hline $\mathrm{CP}$ & 0.74 & 0.81 & 0.032 & 0.05 \\
\hline True protein & 0.69 & 0.76 & 0.031 & 0.04 \\
\hline Casein & 0.58 & 0.64 & 0.025 & 0.03 \\
\hline Fat & 0.91 & 1.03 & 0.051 & 0.04 \\
\hline Lactose & 1.09 & 1.22 & 0.065 & 0.06 \\
\hline Milk urea, $\mathrm{m} M$ & 7.5 & 6.5 & 0.16 & $<0.001$ \\
\hline
\end{tabular}

${ }^{1} \mathrm{SED}=$ standard error of the difference.

${ }^{2}$ Calculated as $(0.4 \times \mathrm{kg}$ of milk/d $)+(15 \times \mathrm{kg}$ of fat $/ \mathrm{d})$ (Gaines and Davidson, 1923).

${ }^{3} \mathrm{NE}_{\mathrm{L}}=4.186 \times[(0.0929 \times$ fat \% $)+(0.0547 \times \mathrm{CP} \%)+(0.0395 \times$ lactose \% $)](\mathrm{NRC}, 2001)$.

of 16.1, 5.0,16.0, and $14.5 \mathrm{mM}$ at 0000, 0600, 1200, and $1800 \mathrm{~h}$. The greatest difference between n-RFI (19.9 $\mathrm{m} M)$ and p-RFI $(12.1 \mathrm{mM})$ groups was at $1200 \mathrm{~h}$.

We observed no differences between RFI groups in rumen pools measured by emptying, and digesta weights increased by approximately $17 \mathrm{~kg}$ as a consequence of eating (Table 6). The rumen DM contents in n-RFI and p-RFI cows did not differ, and DM pools increased by about $2.5 \mathrm{~kg}$ with eating. The DM content of rumen digesta in n-RFI cows $(8.89 \%)$ was not different $(P=$ 0.09 ) from that in the p-RFI cows $(9.55 \%)$, and water intake was similar between n-RFI and p-RFI cows (16.4 vs. $20.2 \pm 3.2 \mathrm{~L} / \mathrm{d} ; P<0.25)$.
The rumen liquid volume, determined by Co-EDTA dilution, appeared to be lower $(P=0.01)$ for $n-R F I$ cows, which also had slower FOR $(P=0.02)$ than p-RFI cows. Consequently, rumen fractional dilution was similar for n-RFI and p-RFI cows (0.21 vs. $0.18 \pm$ $0.013 ; P=0.06)$.

\section{Microbial Community Structure}

We observed no differences between the archaeal and fungal communities of the 2 RFI phenotypes or between the 2 sampling days. Ciliate protozoa varied in only one component between the 2 sampling days and

Table 5. Rumen metabolites and $\mathrm{pH}$ of lactating cows selected for negative residual feed intake (n-RFI) and positive residual feed intake ( $\mathrm{p}-\mathrm{RFI})$ and fed high-quality pasture

\begin{tabular}{lcccc}
\hline Item & n-RFI & p-RFI & SED $^{1}$ & $P$-value \\
\hline $\mathrm{NH}_{3}, \mathrm{~m} M$ & 15.5 & 12.9 & 0.81 & $<0.01$ \\
Acetate, $\mathrm{m} M$ & 88.0 & 89.3 & 3.29 & 0.70 \\
Propionate, $\mathrm{m} M$ & 30.4 & 31.5 & 1.24 & 0.40 \\
Butyrate, $\mathrm{m} M$ & 16.6 & 16.7 & 0.75 & 0.91 \\
Valerate, $\mathrm{m} M$ & 2.5 & 3.0 & 0.46 & 0.32 \\
Isobutyrate, $\mathrm{m} M$ & 1.7 & 1.7 & 0.099 & 0.19 \\
Isovalerate, $\mathrm{m} M$ & 2.7 & 3.0 & 0.25 & 0.29 \\
Total VFA, ${ }^{2} \mathrm{~m} M$ & 142.0 & 145.2 & 5.27 & 0.55 \\
$\mathrm{~A} / \mathrm{T}^{3}$ & 0.62 & 0.62 & 0.007 & 0.67 \\
$\mathrm{P} / \mathrm{T}^{3}$ & 0.21 & 0.22 & 0.006 & 0.64 \\
$\mathrm{~A} / \mathrm{P}^{3}$ & 2.9 & 2.9 & 0.11 & 0.80 \\
$(\mathrm{~A}+\mathrm{B}) / \mathrm{P}^{3}$ & 3.5 & 3.4 & 0.12 & 0.69 \\
$\mathrm{pH}$ & 6.11 & 6.09 & 0.04 & 0.53 \\
\hline
\end{tabular}

${ }^{1} \mathrm{SED}=$ standard error of the difference.

${ }^{2}$ Acetate + propionate + butyrate + valerate + isobutyrate + isovalerate.

${ }^{3} \mathrm{~A} / \mathrm{T}=$ acetate/total VFA; $\mathrm{P} / \mathrm{T}=$ propionate/total VFA; $\mathrm{A} / \mathrm{P}=$ acetate/propionate; $(\mathrm{A}+\mathrm{B}) / \mathrm{P}=($ acetate + butyrate)/propionate. 
Table 6. Rumen digesta pools measured by emptying and liquid kinetics determined by cobalt-EDTA dilution in cows selected for negative residual feed intake (n-RFI) and positive residual feed intake (p-RFI) and fed high-quality pasture

\begin{tabular}{lcccc}
\hline Item & n-RFI & p-RFI & SED $^{1}$ & $P$-value \\
\hline Rumen pools by emptying & & & & \\
Pre-feeding DM, kg & 6.1 & 7.0 & 0.84 & 0.24 \\
Post-feeding DM, kg & 8.5 & 9.6 & 0.84 & 0.24 \\
Pre-feeding liquid, kg & 65 & 69 & 5.4 & 0.56 \\
$\quad$ Post-feeding liquid, kg & 83 & 85 & 5.3 & 0.56 \\
Rumen marker dilution & & & & \\
$\quad$ Rumen liquid volume, L & 53.4 & 75.5 & 7.51 & 0.01 \\
$\quad$ Rumen liquid outflow rate, L/h & 10.8 & 13.1 & 0.86 & 0.02 \\
Rumen fractional dilution $^{2}$ & 0.21 & 0.18 & 0.013 & 0.06 \\
\hline
\end{tabular}

${ }^{1} \mathrm{SED}=$ standard error of the difference.

${ }^{2}$ Rumen fractional dilution $=1-$ antilog slope of cobalt dilution. The marker was administered during the morning feeding period.

not between the 2 RFI phenotypes. Some differences were observed in the bacterial community between the 2 sampling days and RFI phenotypes, but no conclusive patterns were identified in the changes of the microbial community structure (Table 7 ). We found no evidence of an interaction between RFI phenotype and sampling day. Comparison of community patterns by principal component analysis failed to reveal patterns relating to sampling day or RFI group (data not shown).

\section{DISCUSSION}

\section{Digestibility Study}

The cows evaluated here were selected for divergence in RFI for BW gain at 6 to 8 mo of age, and the divergent groups had a similar genetic potential (breeding worth) for lifetime milk production (Waghorn et al., 2012). Selection did not identify causes for divergence, and only a weak association with behavior has been reported (Green et al., 2011). In the experiment presented here, cows with the n-RFI phenotype differed from the p-RFI cows in their apparent digestibility for $\mathrm{N}$ and DM, with some associations with rumen function. Incidentally, this trial was not designed to assess efficiency for milk production. The differences in digestibility are consistent with those of Nkrumah et al. (2006), who reported a trend for greater DM and CP digestibility in n-RFI compared with p-RFI steers ( 75 vs. $70 \%$ for DM digestibility and 73 vs. $69 \%$ for CP digestibility). The digestibility study of Nkrumah et al. (2006) consisted of a 5 -d period of total collection of feces and urine and is comparable to our study. Moreover, Nkrumah et al. (2006) reported a negative correlation between RFI and apparent digestibility of DM $(\mathrm{r}=-0.33)$ and $\mathrm{CP}(\mathrm{r}=$ -0.34 ), indicating an association between phenotype and digestibility.
Krueger et al. (2009a) also reported greater DM digestibility for n-RFI than for p-RFI heifers (76 vs. 73\%), as well as a greater CP digestibility in n-RFI heifers, based on fecal grab samples and using acid-insoluble ash as a marker. These differences in digestibility between phenotypes are in contrast to the reports of Cruz et al. (2010) and Lawrence et al. (2011), who did not find effects on DM digestibility after selection for divergence in RFI in either steers or heifers. However, both of these studies relied on internal markers (lignin and acid-insoluble ash) to estimate digestibility from fecal grab samples, whereas the data obtained in the experiment reported here were based on total collection. Systematic and random errors can increase markedly when using internal markers, which limits the ability to detect differences in digestibility of 1 to $2 \%$. Therefore, measures of digestibility in our study agree with the observations of Nkrumah et al. (2006) and suggest that greater DM, OM, and $\mathrm{N}$ digestibility could affect efficiency of nutrient utilization in n-RFI and p-RFI cows. Total collection of output (e.g., feces, urine, and milk) appears to detect consistently small differences of digestibility in cattle differing in RFI.

\section{Nitrogen Digestion and Utilization}

In contrast to the greater digestibility by n-RFI cows, those selected for p-RFI partitioned a greater percentage of $\mathrm{N}$ intake into milk protein and, in particular, casein. In this short trial, the p-RFI cows yielded more $4 \% \mathrm{FCM}$, probably because they consumed 0.5 $\mathrm{kg}$ more $\mathrm{DM} / \mathrm{d}$, and they had higher casein and lower urea concentrations in milk, possibly associated with lower rumen $\mathrm{NH}_{3}$ concentrations, suggesting a lower proteolysis compared with n-RFI animals. Reports of greater efficiency of rumen $\mathrm{N}$ utilization associated with declining rumen $\mathrm{NH}_{3}$ concentrations (Bach et al., 
Table 7. Rumen microbial community compositions of lactating cows selected for negative residual feed intake (n-RFI) and positive residual feed intake (p-RFI) and fed high-quality pasture determined at d 2 and 6 of the experimental period

\begin{tabular}{|c|c|c|c|c|c|c|c|c|}
\hline \multirow[b]{2}{*}{ Microbial group $^{1}$} & \multicolumn{2}{|c|}{$\begin{array}{l}\text { Abundance } \\
\text { in n-RFI, }{ }^{2} \%\end{array}$} & \multicolumn{2}{|c|}{$\begin{array}{l}\text { Abundance } \\
\text { in p-RFI, \% }\end{array}$} & \multirow[b]{2}{*}{$\mathrm{SED}^{3}$} & \multicolumn{3}{|c|}{$P$-value } \\
\hline & $\mathrm{d} 2$ & d 6 & $\mathrm{~d} 2$ & d 6 & & RFI & Day & $\mathrm{RFI} \times$ day \\
\hline \multicolumn{9}{|l|}{ Bacteria } \\
\hline Lachnospiraceae & 30.2 & 26.6 & 26.0 & 22.9 & 1.94 & 0.03 & $<0.01$ & 0.82 \\
\hline Prevotellaceae & 19.4 & 22.2 & 22.1 & 25.3 & 1.94 & 0.08 & 0.01 & 0.85 \\
\hline Ruminococcaceae & 10.7 & 11.0 & 11.0 & 11.2 & 0.62 & 0.61 & 0.39 & 0.93 \\
\hline Erysipelotrichaceae & 6.9 & 7.4 & 9.3 & 8.8 & 1.86 & 0.26 & 1.0 & 0.56 \\
\hline Fibrobacteraceae & 2.1 & 3.0 & 3.1 & 3.5 & 0.53 & 0.04 & 0.13 & 0.52 \\
\hline Veillonellaceae & 2.8 & 2.7 & 2.6 & 2.6 & 0.37 & 0.59 & 0.94 & 0.82 \\
\hline Clostridiales family XIII & 1.2 & 1.3 & 0.9 & 1.1 & 0.18 & 0.06 & 0.38 & 0.67 \\
\hline Coriobacteriaceae & 1.1 & 1.0 & 1.1 & 1.1 & 0.25 & 0.75 & 0.84 & 0.81 \\
\hline \multicolumn{9}{|l|}{ Archaeal } \\
\hline Methanobrevibacter gottschalkii clade & 47.3 & 49.1 & 41.1 & 43.9 & 4.47 & 0.19 & 0.21 & 0.77 \\
\hline Dasytricha & 30.4 & 27.4 & 22.6 & 18.6 & 5.09 & 0.09 & 0.13 & 0.82 \\
\hline Isotricha & 7.0 & 11.3 & 6.1 & 7.5 & 1.98 & 0.21 & $<0.01$ & 0.12 \\
\hline Eremoplastron-Diploplastron & 1.9 & 3.1 & 2.5 & 2.6 & 1.34 & 1.00 & 0.21 & 0.28 \\
\hline \multicolumn{9}{|l|}{ Fungi } \\
\hline Piromyces 7 & 31.5 & 31.5 & 36.4 & 33.24 & 6.58 & 0.60 & 0.52 & 0.53 \\
\hline Piromyces 2 & 23.8 & 23.6 & 29.4 & 27.6 & 4.46 & 0.25 & 0.62 & 0.70 \\
\hline Neocallimastix 1 & 22.1 & 25.5 & 14.9 & 17.7 & 8.78 & 0.34 & 0.49 & 0.95 \\
\hline SK3 & 13.6 & 11.6 & 15.4 & 15.2 & 11.4 & 0.81 & 0.54 & 0.59 \\
\hline SK1 & 2.0 & 2.8 & 1.3 & 1.8 & 0.66 & 0.07 & 0.21 & 0.77 \\
\hline Piromyces 3 & 3.0 & 2.1 & 0.5 & 2.0 & 2.89 & 0.65 & 0.74 & 0.19 \\
\hline GQ850335-related & 1.4 & 1.3 & 1.3 & 1.1 & 0.34 & 0.60 & 0.17 & 0.38 \\
\hline Piromyces 6 & 1.9 & 1.1 & 0.3 & 1.0 & 1.74 & 0.59 & 0.90 & 0.19 \\
\hline
\end{tabular}

${ }^{1}$ Bacterial families were named using the greengenes database (DeSantis et al., 2006). Data from 13 family groups each contributing $<1 \%$ to the bacterial communities are not shown. Archaeal clades were named using the scheme of Janssen and Kirs (2008). Data from 3 clades each contributing $<1 \%$ to the archaeal communities are not shown. Ciliate protozoal genus groups were named using the scheme of Kittelmann and Janssen (2011). Data from 8 genus groups each contributing $<1 \%$ to the ciliate protozoal communities are not shown. Fungal groups were named using the scheme of Kittelmann et al. (2012). Data from 7 groups each contributing $<1 \%$ to the fungal communities are not shown.

${ }^{2}$ Average abundances are reported as percentages of the total bacteria, archaeal, ciliate protozoa, or fungi.

${ }^{3}$ Standard error of the difference for comparison of microbial groups in samples from cows selected for n-RFI and p-RFI, treating each sample day as a separate comparison.

2005; Broderick and Reynal, 2009) are unlikely to apply when $\mathrm{CP}$ intakes exceed requirements, as in the current experiment. Nonetheless, the higher degradation of ryegrass $\mathrm{CP}$ and increasing rumen $\mathrm{NH}_{3}$ concentrations in n-RFI cows are wasteful and could reduce the RUP supply to the small intestine. We can find no clear explanation for the lower partition of $\mathrm{N}$ intake to milk in the n-RFI cows other than a lower milk production in the experiment reported here, and the analysis of rumen microflora did not indicate any effect of microbial populations.

The lower partition of $\mathrm{N}$ to feces in the n-RFI phenotype is consistent with the higher digestibility and $\mathrm{NH}_{3}$ concentrations in the rumen, suggesting greater proteolysis and more $\mathrm{N}$ excretion in the urine. Although the partitioning of $\mathrm{N}$ in urine was not significantly differ- ent between RFI phenotypes, a greater value from the n-RFI cows would have been expected in view of the higher rumen $\mathrm{NH}_{3}$ and milk urea concentrations observed in this group. A reduction in urinary $\mathrm{N}$ excretion and a partition toward feces is desirable under grazing, because urinary $\mathrm{N}$ causes $\mathrm{N}$ leaching to groundwater and nitrous oxide emissions that are implicated in climate change.

\section{Rumen Parameters}

The higher concentration of $\mathrm{NH}_{3}$ in the rumen of n-RFI cows fed fresh pasture reported in this study corresponds with numerically greater values of $\mathrm{NH}_{3}$ in n-RFI $(90.5 \mathrm{mg} / \mathrm{L})$ versus p-RFI $(73.5 \pm 8.4 \mathrm{mg} / \mathrm{L})$ in heifers fed a silage plus concentrate-based diet (14\% 
CP; Lawrence et al., 2011). The contrasting diets fed in these studies and the CP contents (23 and 14\%) suggest that different microbial populations in the 2 groups may have contributed to these differences in $\mathrm{NH}_{3}$ concentrations, through either proteolysis or microbial growth. However, analysis of the microbial community structure did not suggest differences in the microflora, but differences in microbial activity or absorption from the rumen could account for contrasting $\mathrm{NH}_{3}$ concentrations. Rumen FOR is not likely to have affected the concentration of $\mathrm{NH}_{3}$, because it was similar in both RFI groups, but variations in chewing, affecting cell rupture and release of soluble $\mathrm{CP}$, could have affected fermentation. Chewing and eating rate were not measured in this study, but Green et al. (2011) showed significant variation between trials and no consistent relationships in meal size, eating rate, and eating duration in heifers with divergent RFI phenotypes.

No effect of the RFI phenotype was found on rumen VFA concentrations or molar proportions in the study reported here, which is in contrast to some other reports. For example, Lawrence et al. (2011) reported a greater proportion of propionate in n-RFI heifers fed a low CP diet of pasture silage plus concentrate, whereas Krueger et al. (2009a) reported a lower proportion of propionate and a lower acetate:propionate ratio in n-RFI heifers fed a high roughage diet. Concentrations of acetate and butyrate were unaffected by RFI, and Krueger et al. (2009b) did not find differences in VFA concentrations in rumen contents of n-RFI and p-RFI steers fed a high grain ration. In contrast, Hernandez-Sanabria et al. (2010) reported lower butyrate and isovalerate concentrations in n-RFI compared with p-RFI steers fed a high grain ration. Lawrence et al. (2011) took samples by esophageal lavage and found no differences in VFA concentrations, as did Hernandez-Sanabria et al. (2010); taking samples by esophageal lavage could have affected VFA concentrations (due to salivary dilution) but not molar ratios. The conflicting relationships between RFI and molar proportions of VFA in cattle fed roughage diets (Krueger et al., 2009a; Lawrence et al., 2011) and the lack of effects reported in this study with pasture or high grain diets fed by Hernandez-Sanabria et al. (2010) do not indicate clear relationships between RFI and molar proportions of VFA. The lack of concentrates in the diets in the current experiment may not have allowed differences in propionate production due to RFI phenotype to manifest themselves, but if this was a characteristic of n-RFI cattle, a response should have been noted by Hernandez-Sanabria et al. (2010) or Krueger et al. (2009b).

Measurements of rumen volume and FOR were undertaken because a small rumen digesta volume, or a high FOR, might have caused a reduction in digestion with associated effects on microbial populations and activity (Janssen, 2010). Basarab et al. (2003) reported a smaller gastrointestinal tract in n-RFI steers, which could reduce energy costs of maintenance and still accommodate the lower intakes associated with negative RFI. Depending upon diets and intakes, cows selected for n-RFI might also compensate for the smaller rumen digesta volume with a higher FOR. Alternatively, a larger rumen volume and lower FOR could result in higher digestibility and nutrient capture in n-RFI cows, but the estimations made in this study suggest similar FOR in both phenotypes. The rumen emptying showed a similar rumen digesta weight for both phenotypes and, although the rumen liquid pool weight appeared smaller in n-RFI cows than in p-RFI cows, it is important to emphasize that the cows were not at steady state (cows were fed twice daily) and that a small increase in rumen volume associated with eating (Table 6). However, the log-transformed Co concentrations were linear for all cows, suggesting minor changes in rumen steady state (Warner and Stacy, 1968).

Although the improved digestibility in n-RFI cows cannot be explained from rumen digesta weights and rumen liquid kinetics, differences in rumen parameters could have contributed to differences in digestibility in this and other studies (Titgemeyer, 1997).

\section{Rumen Microflora}

We detected minor effects of both sampling day and RFI phenotype on the rumen microbial communities (bacteria, archaea, ciliate protozoa, and fungi). This differs from a report by Wiley et al. (2011), which concluded that more structural carbohydrate-degrading bacteria may have been present in n-RFI Brahman bulls, although proteolytic bacteria did not differ between the 2 RFI groups of bulls when forage was not limiting when grazing large allowances of bermudagrass (Cynodon dactylon). Wiley et al. (2011) identified bacterial populations using a pyrosequencing technique similar to the one used in this study. Their finding is in line with Hernandez-Sanabria et al. (2010), who used PCR-denaturing gradient gel electrophoresis to report minor differences in the microflora. The current trial results of protozoal, fungal, and archaeal communities in lactating dairy cows with divergence for RFI phenotype appear to be novel and do not suggest meaningful differences associated with this trait.

The absence of differences in the rumen microflora in our study is in line with the lack of differences in VFA concentrations and molar ratios in this and other studies. The higher rumen $\mathrm{NH}_{3}$ concentrations in n-RFI ani- 
mals, as well as whole-tract apparent digestibility of $\mathrm{N}$, do suggest differences in digestion, but the absence of a conclusive pattern in the microbial community analysis did not suggest changes in microflora associated with RFI phenotype. In conclusion, DM, OM, and $\mathrm{N}$ digestibilities were greater in n-RFI than in p-RFI cows but effects were not associated with rumen digesta volume or kinetics or the rumen microflora. The differences in digestibility between divergent RFI phenotype reported here and elsewhere require further research.

\section{ACKNOWLEDGMENTS}

The authors acknowledge the assistance of Lye Farm staff and technicians, D. Day for laboratory analysis and B. Dow for statistical analysis (both of DairyNZ), and the DairyNZ research team in preparing this manuscript. This work was funded by the New Zealand dairy farmers, through DairyNZ Inc. (Hamilton, New Zealand) and the Ministry of Agriculture and Forestry through Sustainable Land Management Mitigation and Adaptation to Climate Change Project No 0803.

\section{REFERENCES}

Bach, A., S. Calsamiglia, and M. D. Stern. 2005. Nitrogen metabolism in the rumen. J. Dairy Sci. 88(E-Suppl.):9-21.

Basarab, J. A., M. A. Price, J. L. Aalhus, E. K. Okine, W. M. Snelling, and K. L. Lyle. 2003. Residual feed intake and body composition in young growing cattle. Can. J. Anim. Sci. 83:189-204.

Broderick, G. A., and S. M. Reynal. 2009. Effect of source of rumendegraded protein on production and ruminal metabolism in lactating dairy cows. J. Dairy Sci. 92:2822-2834.

Caporaso, J. G., J. Kuczynski, J. Stombaugh, K. Bittinger, F. D. Bushman, E. K. Costello, N. Fierer, A. Gonzalez Pena, J. K. Goodrich, J. I. Gordon, G. A. Huttley, S. T. Kelley, D. Knights, J. E. Koenig, R. E. Ley, C. A. Lozupone, D. McDonald, B. D. Muegge, M. Pirrung, J. Reeder, J. R. Sevinsky, P. J. Turnbaugh, W. A. Walters, J. Widmann, T. Yatsunenko, J. Zaneveld, and R. Knight. 2010. QIIME allows analysis of high-throughput community sequencing data. Nat. Methods 7:335-336.

Carnie, K. R., S. R. Davis, K. A. Macdonald, G. C. Waghorn, V. V. Obolonkin, and R. J. Spelman. 2010. Variation in feed conversion efficiency in Holstein-Friesian heifer calves. Proc. N.Z. Soc. Anim. Prod. 70:250-252.

Cruz, G. D., J. A. Rodríguez-Sánchez, J. W. Oltjen, and R. D. Sainz. 2010. Performance, residual feed intake, digestibility, carcass traits, and profitability of Angus-Hereford steers housed in individual or group pens. J. Anim. Sci. 88:324-329.

Cyriac, J., A. G. Rius, M. L. McGilliard, R. E. Pearson, B. J. Bequette, and M. D. Hanigan. 2008. Lactation performance of midlactation dairy cows fed ruminally degradable protein at concentrations lower than National Research Council recommendations. J. Dairy Sci. 91:4704-4713.

DeSantis, T. Z., P. Hugenholtz, N. Larsen, M. Rojas, E. L. Brodie, K. Keller, T. Huber, D. Dalevi, P. Hu, and G. L. Andersen. 2006. Greengenes, a chimera-checked 16S rRNA gene database and workbench compatible with ARB. Appl. Environ. Microbiol. 72:5069-5072.

Fierer, N., M. Hamady, C. L. Lauber, and R. Knight. 2008. The influence of sex, handedness, and washing on the diversity of hand surface bacteria. Proc. Natl. Acad. Sci. USA 105:17994-17999.
Gaines, W. L., and F. A. Davidson. 1923. Relation between percentage fat content and yield of milk. Vol. 245, Illinois Agric. Exp. Stat. Bull. Illinois Agric. Exp. Stat., Champaign, IL.

Green, T. C., G. C. Waghorn, N. J. Beausoleil, and K. A. Macdonald. 2011. Feeding behaviour differs between dairy calves selected for divergent feed conversion efficiency. Proc. N.Z. Soc. Anim. Prod. $71: 281-285$

Hegarty, R. S., J. P. Goopy, R. M. Herd, and B. McCorkell. 2007. Cattle selected for lower residual feed intake have reduced daily methane production. J. Anim. Sci. 85:1479-1486.

Herd, R. M., and P. F. Arthur. 2009. Physiological basis for residual feed intake. J. Anim. Sci. 87(E-Suppl.):E64-E71.

Hernandez-Sanabria, E., L. L. Guan, L. A. Goonewardene, M. Li, D. F. Mujibi, P. Stothard, S. S. Moore, and M. C. Leon-Quintero. 2010. Correlation of particular bacterial PCR-denaturing gradient gel electrophoresis patterns with bovine ruminal fermentation parameters and feed efficiency traits. Appl. Environ. Microbiol. 76:6338-6350.

Horowitz, W., and G. W. Latimer. 2005. Official Methods of Analysis. 18th ed. Association of Official Analytical Chemists International, Gaithersburg, MD.

Janssen, P. H. 2010. Influence of hydrogen on rumen methane formation and fermentation balances through microbial growth kinetics and fermentation thermodynamics. Anim. Feed Sci. Technol. $160: 1-22$.

Janssen, P. H., and M. Kirs. 2008. Structure of the archaeal community of the rumen. Appl. Environ. Microbiol. 74:3619-3625.

Kittelmann, S., G. E. Naylor, J. P. Koolaard, and P. H. Janssen. 2012. A proposed taxonomy of anaerobic fungi (class Neocallimastigomycetes) suitable for large-scale sequence-based community structure analysis. PLoS ONE 7:e36866.

Kittelmann, S., and P. H. Janssen. 2011. Characterization of rumen ciliate community composition in domestic sheep, deer, and cattle, feeding on varying diets, by means of PCR-DGGE and clone libraries. FEMS Microbiol. Ecol. 75:468-481.

Krueger, W. K., G. E. Carstens, R. R. Gomez, B. M. Bourg, P. A. Lancaster, L. J. Slay, J. C. Miller, R. C. Anderson, S. M. Horrocks, N. A. Kreuger, and T. D. A. Forbes. 2009a. Relationships between residual feed intake and apparent nutrient digestibility, in vitro methane producing activity and VFA concentrations in growing Brangus heifers. J. Anim. Sci. 87(E-Suppl. 2):153. (Abstr.)

Krueger, W. K., G. E. Carstens, Z. D. Paddock, T. R. Calloway, R.C. Anderson, N. A. Kreuger, V. Gontcharova, S. E. Dowd, R. R. Gomez, and W. E. Pinchak. 2009b. Associations between feed efficiency and gut microbial ecology and fermentation parameters in feedlot cattle. J. Anim. Sci. 87(E-Suppl. 2):295-296. (Abstr.)

Lawrence, P., D. A. Kenny, B. Earley, D. H. Crews Jr., and M. McGee. 2011. Grass silage intake, rumen and blood variables, ultrasonic and body measurements, feeding behavior and activity in pregnant beef heifers differing in phenotypic residual feed intake. J. Anim. Sci. 89:3248-3261.

Meier, S., P. J. S. Gore, C. M. E. Barnett, R. T. Cursons, D. E Phipps, K. A. Watkins, and G. A. Verkerk. 2008. Metabolic adaptations associated with irreversible glucose loss are different to those observed during under-nutrition. Domest. Anim. Endocrinol. 34:269-277.

NRC. 2001. Nutrient Requirements of Dairy Cattle. 7th rev. ed. Natl. Acad. Sci., Washington, DC.

Nkrumah, J. D., E. K. Okine, G. W. Mathison, K. Schmid, C. Li, J. A. Basarab, M. A. Price, Z. Wang, and S. S. Moore. 2006. Relationships of feedlot feed efficiency, performance, and feeding behavior with metabolic rate, methane production, and energy partitioning in beef cattle. J. Anim. Sci. 84:145-153.

Richardson, E. C., R. M. Herd, P. F. Arthur, J. Wright, G. Xu, K. Dibley, and V. H. Oddy. 1996. Possible physiological indicators for net feed conversion efficiency in beef cattle. Proc. Aust. Soc. Anim. Prod. 21:103-106.

Rius, A. G., M. L. McGilliard, C. Umberger, and M. D. Hanigan. 2010. Interactions of energy and predicted metabolizable protein in determining nitrogen efficiency in the lactating dairy cow. J. Dairy Sci. 93:2034-2043. 
Robertson, J. B., and P. J. Van Soest. 1981. The detergent system of analysis and its application to human foods. Pages 123-158 in The Analysis of Dietary Fiber in Foods. W. P. T. James and O. Theander, ed. Marcel Dekker, New York, NY.

Titgemeyer, E. C. 1997. Design and interpretation of nutrient digestion studies. J. Anim. Sci. 75:2235-2247.

Udén, P., P. E. Colucci, and P. J. Van Soest. 1980. Investigation of chromium, cerium and cobalt as markers in digesta: Rate of passage studies. J. Sci. Food Agric. 31:625-632.

Van Vuuren, A. M., F. Krol-Kramer, R. A. Van der Lee, and H. Corbijn. 1992. Protein digestion and intestinal amino acids in dairy cows fed fresh Lolium perenne with different nitrogen contents. J. Dairy Sci. 75:2215-2225.

Waghorn, G. C., K. A. Macdonald, Y. Williams, S. R. Davis, and R. J. Spelman. 2012. Measuring residual feed intake in dairy heifers fed an alfalfa (Medicago sativa) cube diet. J. Dairy Sci. 95:1462-1471.
Warner, A. C. I., and B. D. Stacy. 1968. The fate of water in the rumen. Br. J. Nutr. 22:369-387.

Weimer, P. J., D. M. Stevenson, H. C. Mantovani, and S. L. C. Man. 2010. Host specificity of the ruminal bacterial community in the dairy cow following near-total exchange of ruminal contents. J. Dairy Sci. 93:5902-5912.

Wiley, L. M., L. O. Tedeschi, T. D. A. Forbes, F. M. Rouquette Jr., R. D. Randel, F. R. B. Ribeiro, and S. E. Dowd. 2011. A comparison of ruminal and large intestinal microbial population of residual feed intake-indexed Brahman bulls under grazing conditions. J. Anim. Sci. 89(E-Suppl. 2):2. (Abstr.)

Wronkowska, M., M. Soral-Smietana, U. Krupa, and E. Biedrzycka. 2006. In vitro fermentation of new modified starch preparationschanges of microstructure and bacterial end-products. Enzyme Microb. Technol. 40:93-99. 